\title{
Impact of Intravenous Antibiotic Therapy on Total Daily Energy Expenditure and Physical Activity in Cystic Fibrosis Children with Pseudomonas aeruginosa Pulmonary Exacerbation
}

\author{
LAURENT BÉGHIN, FRÉDÉRIC GOTTRAND, LAURENT MICHAUD, GUY-ANDRÉ LOEUILLE, \\ NATHALIE WIZLA-DERAMBURE, ANNE SARDET, DOMINIQUE GUIMBER, \\ ANTOINE DESCHILDRE, AND DOMINIQUE TURCK
}

Division of Gastroenterology, Hepatology and Nutrition, and Cystic Fibrosis Center, Department of Paediatrics, Jeanne de Flandre University Children's Hospital and Faculty of Medicine [L.B., F.G., L.M., G.-A.L., N.W.-D., A.S., D.G., A.D., D.T.], and Clinical Research Center, CIC-9301-INSERM-CHU,

University Hospital [L.B.], Lille, France.

\begin{tabular}{|c|c|}
\hline \multicolumn{2}{|c|}{ ABSTRACT } \\
\hline $\begin{array}{l}\text { Resting energy expenditure (REE) increases during pulmo- } \\
\text { nary exacerbation by Pseudomonas aeruginosa in cystic fibrosis } \\
\text { (CF) patients, and decreases after i.v. anti-Pseudomonas aerugi- } \\
\text { nosa antibiotic therapy (IVAT). However, the impact of IVAT } \\
\text { on total energy expenditure (TEE) is unknown. The aim of this } \\
\text { study was to assess the changes in TEE and its main components } \\
\text { after IVAT administered at home. Body composition measured } \\
\text { by skinfold thickness and bio-impedance analysis, energy intake } \\
\text { (EI) assessed by a weekly diary, REE measured by indirect } \\
\text { calorimetry (IC), TEE assessed by a technique using } 24 \text {-h heart- } \\
\text { rate monitoring method and physical activity (PA) monitored } \\
\text { using an activity diary (AD) were assessed in } 16 \text { patients ( } 9 \text { boys } \\
\text { and } 7 \text { girls) aged } 12.1 \pm 2.3 \text { y (range, } 7.1-14.6 \text { y), before and } \\
\text { after } 28 \pm 4 \text { d including a } 14-\mathrm{d} \text { IVAT course. After IVAT, } \\
\text { weight increased significantly by } 1.9 \%(32.1 \pm 7.5 \text { versus } 32.7 \\
\pm 7.6 \mathrm{~kg} ; p<0.05), \text { while fat mass and fat free mass increased } \\
\text { non significantly. EI increased by } 4.6 \%(10,797 \pm 3,039 \text { versus } \\
11,320 \pm 3,074 \mathrm{~kJ} / \mathrm{d} \text {; } p<0.05) \text { TEE was not affected by IVAT } \\
(7,014 \pm 1,929 \text { versus } 7,081 \pm 1,478 \mathrm{~kJ} / \mathrm{d}) \text { whereas REE } \\
\text { decreased by } 4.1 \%(5,295 \pm 909 \text { versus } 5,093 \pm 837 \mathrm{~kJ} / \mathrm{d} \text {; } p< \\
0.05), \text { resulting in } 9.3 \% \text { increase in PA assessed by AD converted } \\
\text { to metabolic equivalent tasks (MET) }(37.0 \pm 3.1 \text { versus } 40.7 \pm\end{array}$ & $\begin{array}{l}\text { Abbreviations } \\
\text { AD, activity diary } \\
\text { CF, cystic fibrosis } \\
\text { EE, energy expenditure } \\
\text { EI, energy intake } \\
\text { FFM, fat free mass } \\
\text { FM, fat mass } \\
\text { HR, heart rate } \\
\text { HRMT, heart rate monitoring technique } \\
\text { IC, indirect calorimetry } \\
\text { IVAT, i.v. anti-Pseudomonas aeruginosa } \text { antibiotic therapy } \\
\text { PA, physical activity } \\
\text { REE, resting energy expenditure } \\
\text { TEE, total energy expenditure } \\
\text { EE, energy expenditure }\end{array}$ \\
\hline
\end{tabular}

Prognosis and pulmonary function are highly correlated with nutritional status in patients with cystic fibrosis (CF) (1). Many factors, alone or combined, contribute to malnutrition in $\mathrm{CF}: 1$ ) reduced energy intake according to recommended dietary al-

Received May 14, 2002; accepted March 4, 2003.

Correspondence: F. Gottrand, Unité de Gastroentérologie, Hépatologie et Nutrition, Clinique de Pédiatrie, Hôpital Jeanne de Flandre, 2, Avenue Oscar Lambret, 59037 Lille, France; e-mail: fgottrand@chru-lille.fr

Supported by grants from the French Ministry of Health ("Hospital Program for Clinical Research": 1997, number: 1901 and "Vaincre la Mucoviscidose": 1997).

DOI: 10.1203/01.PDR.0000086020.21796.8B lowances (2) increased energy loss (3) increased resting energy expenditure (REE) with or without changes in total energy expenditure (TEE) (4-8). Nutritional status correlates with the severity of the disease (9), and is one of the central considerations in CF management (3). In $50 \%$ of CF patients, chronic pulmonary infection by Pseudomonas aeruginosa is present and may also play a role in malnutrition (10-12). Previous studies have shown that i.v. anti-Pseudomonas aeruginosa therapy (IVAT) can improve nutritional status, but the mechanisms underlying this phenomenon are not well understood (13-16). Any increase in REE and/or TEE in CF patients, at 
baseline and/or during pulmonary exacerbation, is important because it may contribute to a negative energy balance and malnutrition.

Total energy needs comprise the summation of energy required at rest $(50 \%$ to $60 \%)$, for exercise $(30 \%$ to $40 \%)$, for food metabolism, and for growth in children (17). Several authors have reported REE in CF patients to be $10 \%$ to $30 \%$ higher than predicted $(15,18-22)$ or than in controls matched for age, sex, and weight $(23,24)$. Mechanisms leading to increased REE may include the genetic defect underlying $\mathrm{CF}$, the energy cost of breathing, and the systemic effects of excessive chronic pulmonary inflammation $(24,25)$ and it has been shown that REE decreases after IVAT (15, 26-28). The impact on TEE of IVAT used to treat Pseudomonas aeruginosa pulmonary exacerbation is unknown. The aim of the present study was to assess the changes in TEE, REE, and physical activity after home-administered IVAT.

\section{PATIENTS AND METHODS}

Patients. The study was carried out during years 1999 to 2001. During this period, the Cystic Fibrosis Center of Lille followed $122 \mathrm{CF}$ patients. CF patients were selected for the present study if they were aged between 5 and $18 \mathrm{y}$, were chronically colonized with Pseudomonas aeruginosa (the presence of Pseudomonas aeruginosa in three consecutive sputum analyses over a 6-mo period). Noninclusion criteria were cardiac insufficiency, cardiac rhythm abnormalities, treatment with beta-blockers, oxygen therapy, and lung transplantation. Patients were excluded from the study if they required hospitalization, treatment with corticosteroids, or presented with any acute condition (such as extra-pulmonary infection) known to interfere with energy expenditure (EE), during the study period. From this population, 34 patients met the selection criteria. All 34 were contacted to participate at the study and finally 16 were included when they required home IVAT for pulmonary exacerbation (presence of Pseudomonas aeruginosa in sputum analyze) and a Smith score higher than 5/10 (29). Six children refused to participate, 8 were not included because they received antibiotics course during school summer holidays (and could not be studied during a school day), and 4 could not be included for technical reason (equipment for the study not available at the time of their antibiotic courses). The sixteen children and adolescents with CF included were 9 boys and 7 girls aged $12.1 \pm 2.3$ (mean \pm SD) years (range, 7.1-14.6 y) with a mean Shwachman score of $75 \pm 10$ (median: 80 range: 65-90) and a forced expiration volume in $1 \mathrm{~s}$ of $67 \pm 25 \%$ of theoretical values. At inclusion in the study, Z-score for weight/height was above $-2 \mathrm{SD}$ (mean: $-0.3 \pm 1$ ) according to French population (30) for all patients, but only one who was slightly malnourished (Z-score: -2.3 ).

All procedures were performed in accordance with the ethical standards of the Helsinki Declaration of 1975, as revised in 1983. Before the study began, the purpose and the objectives were carefully explained to participants. Written informed consent was obtained from both children and parents, and the study was approved by the Lille University Ethics Committee
(Comité Consultatif de Protection des Personnes dans la Recherche Biomédicale de Lille).

Study protocol. Each subject was studied twice 3-7 d before the administration of IVAT, and 5-10 d after the completion of the 14-d IVAT. During the first visit to the hospital, the child underwent body composition assessment, REE measurement, and calibration of energy expenditure with heart rate. At that time, the 7-d food record was reviewed by the same dietitian. The following day, heart rate and physical activity recorded by activity diary were monitored for $24 \mathrm{~h}$ under normal lifestyle conditions during a school day without sporting activity. During a second hospital visit one week after the completion of the 14-d home IVAT (so, $28 \pm 4 \mathrm{~d}$ after the first visit), the food record, body composition, REE, and the calibration equation for heart rate and energy expenditure were again assessed, 28 $\pm 4 \mathrm{~d}$ after the first evaluation. The following day, HR and PA were simultaneously recorded for $24 \mathrm{~h}$ on the same school day of the week as the first evaluation.

Analysis of energy expenditure. The two visits were as followed: on the day of the test, the child arrived by car at the Clinical Research Center of the Lille University Heart Hospital (CIC-9301-INSERM-CHU) at 08:00 h, having fasted from 20:00 $\mathrm{h}$ on the previous day. The child then rested recumbent on a hospital bed watching a videotape. The same quiet cartoon of $1 \mathrm{~h} 30 \mathrm{~min}$ duration was used for all the children. As the adaptation period was $15 \mathrm{~min}$ under the ventilated canopy system and REE was measured for $30 \mathrm{~min}$, children watched the same cartoon during the two sessions: the first 45 min were seen during the first session before IVAT and the last $45 \mathrm{~min}$ during the second session after IVAT.

Oxygen consumption $\left(\dot{\mathrm{V}}_{2}\right.$ in $\left.\mathrm{mL} / \mathrm{min}\right)$ and carbon dioxide production $\left(\dot{\mathrm{V}}_{\mathrm{CO}_{2}}\right.$ in $\left.\mathrm{mL} / \mathrm{min}\right)$ using the validated instrument Deltatrac II (Datex Instrumentation Corporation, Helsinki, Finland) were measured every minute. The validity and accuracy of expired carbon dioxide $\left(\dot{\mathrm{V}}_{\mathrm{CO}_{2}}\right)$ and inspired oxygen $\left(\dot{\mathrm{V}}_{2}\right)$ flows, the respiration quotient (RQ), and flow settings were calibrated every 6 mo with reference to alcohol combustion by the manufacturer of the calorimeter. The manufacturer certified a coefficient of variation $(\mathrm{CV})$ of $<2 \%$ for each measurement of $\dot{\mathrm{V}}_{\mathrm{CO}_{2}}$ and $\dot{\mathrm{V}}_{2}$ flows and the RQ. Values automatically selected to compute individual REE using the Weir formula were those for which the $\mathrm{CV}$ was less than $10 \%$ for both $\dot{\mathrm{V}}_{2}$ and $\dot{\mathrm{V}}_{\mathrm{CO}_{2}}$, and was less than 5\% for RQ (31-33). Values with a higher variation were automatically excluded from REE computing by the "built in sensitive artifact algorithm" of the Deltatrac II. This procedure gave a CV less than $6 \%$ for REE measurement. In our study, the CV of REE measurement in the same set for one subject using Deltatrac II was indeed less than $5 \%$ (4.92 \pm 1.33 before versus $4.86 \pm 1.24$ after IVAT; $n=$ 16; during $30 \mathrm{~min}$ of measurement). The intra-subject $\mathrm{CV}$ of REE measurement by Deltatrac II has already been evaluated in control by Molnar and Schulze and was less than 3\% (34). Inter-subject $\mathrm{CV}$ of repeated REE measurement has also been evaluated in 8 consecutive sets of measurements in 12 infants by Schulze et al. and was 5.6\% (35).

TEE was assessed using the heart-rate monitoring technique (HRMT) calibrated against indirect calorimetry, according to a recently published procedure $(36,37)$. Briefly, the child was 
fitted with probes for the continuous recording of heart rate (HR) using a silver/silver chloride electrode, with a Holter 24/48-h recorder with two channels for electrocardiographic data (Synesis, ELA Medical, Montrouge, France). The calibration period included different activities such as resting; the postprandial period $1 \mathrm{~h}$ after a nonstandardized breakfast of $1500 \pm 400 \mathrm{~kJ}$, corresponding to $20 \%$ of daily energy requirements for each child (38); and at different levels of physical activity on a cycle ergometer (Philips, Paris, France), beginning at $0 \mathrm{~W}$ and increasing the braking force (by $2.5 \mathrm{~W}$ every $30 \mathrm{~s}$ for children $<12 \mathrm{y}$, and by $2.5 \mathrm{~W}$ every $30 \mathrm{~s}$ for children $>12$ y) to achieve a maximal HR close to the theoretical maximal heart frequency (220 - age in years). This calibration period was used to define an individual regression equation between the HR and EE data. The HR values, defined as the mean of the HRs recorded every minute over the specified periods, were calculated with Synetec software (version 1.1; ELA Medical, Montrouge, France). Several equations using the relationships between HR and EE have already been tested in the literature as in our laboratory $(36,37,39)$. Equations tested were linear or polynomial. The best fit describing the relationship of $\mathrm{HR}$ to $\mathrm{EE}$ was obtained by a polynomial third equation curve (P3): $\mathrm{EE}=\mathrm{a} \times \mathrm{HR}^{3}+\mathrm{b} \times \mathrm{HR}^{2}+\mathrm{c} \times \mathrm{HR}+$ $\mathrm{d}$, (where $\mathrm{a}, \mathrm{b}, \mathrm{c}$, and $\mathrm{d}$ are numeric factors) determined for each subject on the basis of the measurements made at rest, during the postprandial period, and at different levels of physical activity. Mean coefficient of regression " $r$ " of each individual P3 equation before and after IVAT were very close to 1 indicating a good fit (0.98 \pm 0.02 versus $0.98 \pm 0.02)$. Secondly, the smaller mean standard residuals between HR and EE were obtained with the P3 equation $(0.02 \pm 0.01)$ indicating the best fit of this mode of calculation. HMRT method provides a close estimation of TEE with an accuracy of about $2.5 \%$ compared with whole-body calorimetry (40). Previous studies have shown that the precision of calculated TEE using the HRMT is good with a CV less than $5 \%$ as $4.0 \%$ by Livingstone et al. (41) and $4.7 \%$ by Bitar et al. (42). This precision under $5 \%$ is acceptable for determining TEE for individuals. This method has also been validated against the doubly labeled water method and was found suitable for CF patients (7).

Body composition analysis. Weight and height were first measured, then body composition was assessed by both impedancometry and skinfold thicknesses. The child then rested recumbent on a hospital bed for $15 \mathrm{~min}$. Body resistance was measured using a body impedance $50 \mathrm{~Hz}$ meter (BIA 101/S, RJL Systems, Detroit, MI, U.S.A.), and fat free mass (FFM) was calculated with the Schaefer formula using left skinfold thicknesses (43). Triceps, biceps, subscapular, and suprailiac skinfold thicknesses were measured to the nearest $0.1 \mathrm{~mm}$ using a Harpenden caliper (Holtain, Crymmich, UK) according to standard anthropometric measurement previously described (44). Fat mass (FM) was calculated using the Brook formula for children under $12 \mathrm{y}$ and the Durnin and Rahaman formula for children over 12 y $(45,46)$. These two techniques have previously been validated against dual x-ray absorptiometry in children (47).
The precision of body fat measurement using skinfold thicknesses is dependent upon the skill of the anthropometrist and the site measured. In general, an intraindividual CV within 5\% can be attained easily by a properly trained and experienced individual (48). All measurements of skinfold thickness in the present study was made by the same operator (LB) who is well experimented with this technique and has a $\mathrm{CV}$ under $5 \%$ in this technique. The precision of fat free mass measurement using bio-impedance analysis 2\% (49). As any estimate of body composition is limited by technical reasons and/or equation used, we decided to calculate FM and FFM as the mean of values obtained by both methods.

Analysis of physical activity. Physical activity was measured by an activity diary. This method has been validated against DLW as a reference method (50) and gives similar data than HMRT for the assessment of 24-h TEE (51). Children and/or participating parents filled a specific chart report form. This chart was separated in 3 portions of the day: morning, afternoon and evening. All children and/or participating parents were instructed to keep detailed self-reports on the types of behaviors and the times at which these active behaviors began and ended during the 24-h period when an accelerometer and HR monitor were worn simultaneously. A trained staff member (LB) reviewed the self-report sheets and discrepancies were resolved with the parent and child. Activity was converted to multiples of resting metabolic rate using metabolic equivalent tasks (MET) from the compendium of physical activities (52).

Analysis of energy intake. The assessment of energy intake was performed using an estimated dietary record technique as previously described (53). The technique used a specific chart report form on paper. The chart included the date, patient identity, and how to record the foods consumed: the explications were a size instrument such as graduated bowls, cups, dishes, number of spoons. Then, each page corresponding to one day was separated in four parts: breakfast, lunch, dinner, and the nibbling. Lunch and dinner detailed in starter, main course, and desert. Both oral and written instructions were given to each patient and/or parents on how to keep accurate records using the size instrument, and the parents assisted the children in recording, identifying, and quantifying the foods consumed. Subjects recorded detailed daily food intake on the specific chart report form during $7 \mathrm{~d}$.

The same dietitian reviewed each specific chart report. Quantity of all meals and drinks were checked with the same dietitian, the parents and the child together. The dietitian was well trained to identify both miss- and over-reporting and plausibility of food recording. The portion sizes were estimated using a three-dimensional portion size instrument with French current meal food photographs corresponding to an exact quantity of foods (54). All quantity was then calculated using BILNUT software (version 6; Paris, France), which computes energy intake using French foods composition tables (55). This method has been shown to provide unbiased records of energy intake in lean subjects up to 9 y old $(56,57)$ and showed that children aged 8-15 y were able to estimate food quantity to within $\pm 10 \%$ of the amount really eaten, suggesting that 
Table 1. Evolution of weight, fat free mass, fat mass and energy intake in $16 C F$ patients (mean $\pm S D$ )

\begin{tabular}{lcc}
\hline \multicolumn{1}{c}{ Mean $\pm \mathrm{SD}$} & Before & After \\
\hline Weight $(\mathrm{kg})$ & $32.1 \pm 7.5$ & $32.7 \pm 7.6^{*}$ \\
Fat free mass $(\mathrm{kg})$ & $26.7 \pm 6.5$ & $27.1 \pm 6.5$ \\
Fat mass $(\mathrm{kg})$ & $5.7 \pm 2.3$ & $6.3 \pm 2.7$ \\
Energy intake $(\mathrm{kJ} / \mathrm{d})$ & $10,797 \pm 3,039$ & $11,320 \pm 3,074^{*}$ \\
\hline
\end{tabular}

$* p<0.05$ (Wilcoxon rank test).

children could quantity their food intake with reasonable accuracy (57).

Statistical analysis. Variables were compared using the paired nonparametric Wilcoxon rank test (where differences were defined as significant at $p<0.05$ ) using SPSS software (SPSS 7.0 for Windows; Chicago, IL, U.S.A.).

\section{RESULTS}

All 16 patients completed the study. The evolution of their physical characteristics (weight, FFM, FM) and energy intake before and after IVAT are shown in Table 1. After IVAT, weight increased significantly by $1.9 \%$ (32.1 \pm 7.5 versus 32.7 $\pm 7.6 \mathrm{~kg} ; p<0.05$ ) while fat mass and fat free mass increased non-significantly by $6 \%$ and by $1.5 \%$ respectively. Energy intake expressed as the daily mean calculated from data collected over $7 \mathrm{~d}$ increased significantly by $1.9 \%(10,797 \pm$ 3,040 versus $11,320 \pm 3,074 \mathrm{~kJ} / \mathrm{d} ; p<0.05$ ) after IVAT. No correlation was found between evolution of weight and energy intake.

Table 2 shows the evolution of $\dot{\mathrm{V}}_{2}, \dot{\mathrm{V}}_{\mathrm{CO}_{2}}$, RQ, TEE, REE, TEE/REE, and physical activity before and after IVAT. One subject was omitted from the analysis of TEE because of technical problems with the Holter record. One subject was excluded from the analysis of AD because it was not sufficiently detailed. $\dot{\mathrm{V}}_{2}, \dot{\mathrm{V}}_{\mathrm{CO}_{2}}$, and RQ were stable after IVAT. REE decreased by $4.1 \%(5,295 \pm 910$ versus $5,093 \pm 837$ $\mathrm{kJ} / \mathrm{d} ; p<0.05)$, whereas TEE remained stable as well as the ratio TEE/REE.

Physical activity assessed by activity diary significantly increase by $9.3 \%(37.0 \pm 3.1$ versus $40.7 \pm 4.5$ MET; $p<$ $0.05)$. Figure 1 summarizes the changes in energy expenditure and physical activity.

\section{DISCUSSION}

The present study confirms previous data that showed a significant weight gain after IVAT $(13,14,16)$. However we did not observed any significant change in body composition. Bio-impedance analysis and skinfold thicknesses are probably too rough method to see small differences in body compartment. That is the reason why we did not see any difference in FM and FFM between before and after IVAT. In our study, energy intake increased after IVAT and remained higher than TEE before and after IVAT ( $36.8 \pm 24.3$ versus $37.5 \pm 26.5 \%)$ to compensate energy losses and fat malabsorption as recommended by Turck and Michaud (1).

The nature of the study design could not allow to allocate full causality to antibiotic treatment. Indeed, for ethical evident reasons it was impossible to perform this study on a double
Table 2. Evolution of metabolic parameters and physical activity in $16 C F$ patients (mean $\pm S D$ )

\begin{tabular}{lcc}
\hline \multicolumn{1}{c}{ Mean $\pm \mathrm{SD}$} & Before & After \\
\hline $\mathrm{VO}_{2}$ at rest $(\mathrm{L} / \mathrm{min})$ & $186.6 \pm 30.9$ & $184.0 \pm 31.3$ \\
$\mathrm{VCO}_{2}$ at rest $(\mathrm{L} / \mathrm{min})$ & $155.1 \pm 27.4$ & $152.7 \pm 24.7$ \\
$\mathrm{RQ}$ at rest & $0.83 \pm 0.06$ & $0.83 \pm 0.04$ \\
$\mathrm{REE}(\mathrm{kJ} / \mathrm{d})$ & $5,295 \pm 909$ & $5.093 \pm 837^{*}$ \\
$\mathrm{TEE}(\mathrm{kJ} / \mathrm{d})$ & $7,014 \pm 1,929$ & $7,081 \pm 1,478$ \\
$\mathrm{TEE} / \mathrm{REE}$ & $1.34 \pm 0.21$ & $1.39 \pm 0.23$ \\
Physical activity $(\mathrm{MET} / \mathrm{d})$ & $37.0 \pm 3.1$ & $40.7 \pm 4.5^{*}$ \\
\hline
\end{tabular}

$* p<0.05$ (Wilcoxon rank test).

blind randomized study: patients were infected and required antibiotics for standard care, and in this case the use of i.v. placebo at home on central line seems no ethical, particularly in children. However, the improvement of the patients' course, particularly the observed increased in food intake, could not be explained just by study participation or by the fact that CF patients felt better after IVAT and recorded food more completely than before IVAT. The dietitian was indeed well trained to identify both miss- and over-reporting and plausibility of food recording. Energy intake of CF patients is currently assessed in the Cystic Fibrosis Center of Lille as in other CF centers during their usual medical follow-up and patients are used to fill such food questionnaire so that risks of methodological bias were very limited. Moreover, 2 of these subjects showed a $1.6 \%$ and a $27.4 \%$ reduction of energy intake compared with the first food questionnaire at the beginning of the study.

Since TEE did not change significantly after IVAT, the improvement in the nutritional status (weight gain) could be due both to a spontaneous increase in energy intake and a decrease in REE. The mean increase in EI was $523 \mathrm{~kJ} / \mathrm{d}$ after IVAT, corresponding to $14644 \mathrm{~kJ}$ for the entire study period $(28 \pm 4$ d) that could partially explain weight gain. Indeed, the increase of $0.6 \mathrm{~kg}$ of fat mass requires $20900 \mathrm{~kJ}$.

Our study shown a significant decrease of REE after IVAT. The beneficial role of IVAT on REE has already been widely documented in CF patients $(27,58)$. The accuracy of our REE measurement could be checked by the RQ measurement (RQ). Mean RQ measured by indirect calorimetry at rest was similar

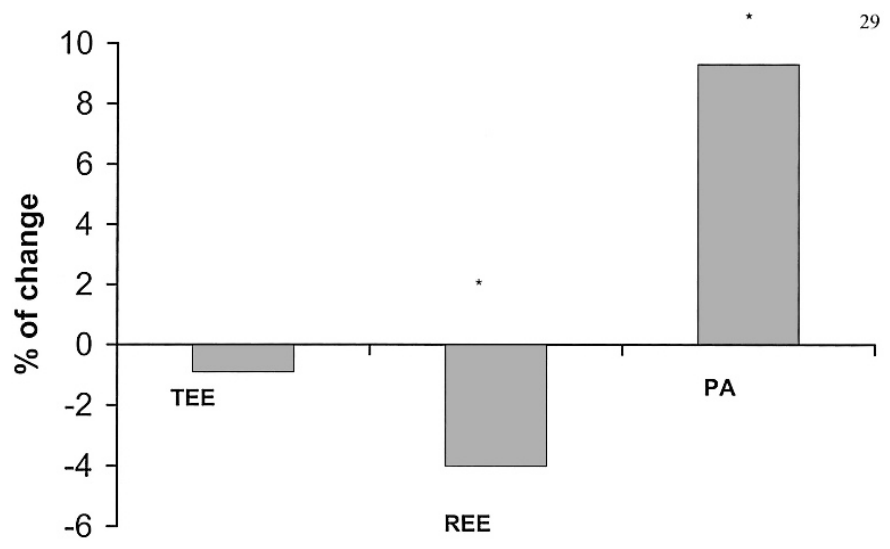

Figure 1. Changes in total energy expenditure, resting energy expenditure, and physical activity before and after IVAT in $16 \mathrm{CF}$ patients. ${ }^{*} p<0.05$ (Wilcoxon rank test). 
in the two sessions (Table 2). RQ at rest of 0.83 and 0.83 (before and after IVAT, respectively) were in agreement with previous data published for cystic fibrosis patients (59). This finding suggested that $\mathrm{CF}$ patients have a normal fasting metabolism and are able to mobilize fat store and oxidized fatty acids after a overnight fast, as controls (60-62). It has been suggested that increased REE in CF patients could be partly due to the genetic defect underlying $\mathrm{CF}$, and secondarily to the energy cost of breathing and the systemic effects of chronic pulmonary inflammation (24). Cystic fibrosis patients has high level circulating inflammation markers at basal state (63) and the significant decrease of REE observed before IVAT could be attributed to a decrease of inflammation as already shown by Burdet et al. (58)

Studies of TEE in clinically well CF patients gave conflicting results. Using the doubly-labeled water method, one study showed an increase of $25 \%$ in TEE, although previous work using the HMRT method showed that free-living 24-h TEE values were similar in stable $\mathrm{CF}$ patients to those of control subjects matched for gender, age, height, and nutritional status $(7,21)$. To the best of our knowledge, there are no published data on the effects of IVAT on TEE. Previous studies showed a mean TEE/REE ratio of 1.55 in $13 \mathrm{CF}$ patients in free-living conditions $(7,21)$. Our study shows a comparable but slightly lower ratio TEE/REE of 1.34 before and 1.39 after IVAT (Table 2). This can be explained by the experimental design of our study: the $16 \mathrm{CF}$ patients we studied were evaluated during a school day without sportive activities, so that physical activity level of our patients could be slightly lower than those of Spicher et al. (21). Our results show that TEE remains stable before and after IVAT although an increase in physical activity was demonstrated by using an activity diary. Analysis of the type of PA in the AD showed that patients are more willing to participate in PA after than before IVAT, probably as a result of their improved aerobic fitness. When patients are studied after IVAT, there was no evidence of the alteration in physical activity levels that is often attributed to $\mathrm{CF}(6,8)$. This spontaneous increase in physical activity is probably beneficial, and may contribute to good nutritional status, an improvement of the quality of life, cardiopulmonary fitness, and bone mineral density.

\section{CONCLUSION}

In conclusion, both the decrease in REE and the improvement in lung function after IVAT promote physical activity in $\mathrm{CF}$ patients, and are therefore helpful in reducing the effects of an inactive lifestyle, as is recommended by most CF referral centers (64). The quality of life of CF patients usually improves after IVAT, which contributes to an improvement in their survival and well-being. The impact of IVAT on the energetic cost of physical activity and the quality of life remains to be determined.

Acknowledgments. We thank the children with $\mathrm{CF}$ and their parents who took part in this study. This study was conducted in the Clinical Research Center of Lille, University Hospital (CIC-9301-INSERM-CHU). We thank Charlotte Buisine, nurse coordinating the CF Center, and Elisabeth Boutry, dietitian, for their invaluable help during the study.

\section{REFERENCES}

1. Turck D, Michaud L 1998 Cystic fibrosis: nutritional consequences and management. Baillieres Clin Gastroenterol 12:805-822

2. Schoni MH, Casaulta-Aebischer C 2000 Nutrition and lung function in cystic fibrosis patients: review. Clin Nutr 219:79-85

3. Doull IJ 2001 Recent advances in cystic fibrosis. Arch Dis Child 85:62-66

4. Tomezsko JL, Stallings VA, Kawchak DA, Goin JE, Diamond G, Scanlin TF 1994 Energy expenditure and genotype of children with cystic fibrosis. Pediatr Res 35:451-460

5. Shepherd RW, Holt TL, Vasques-Velasquez L, Coward WA, Prentice A, Lucas A 1988 Increased energy expenditure in young children with cystic fibrosis. Lancet $1: 1300-1303$

6. Dodge JA, O'Rawe AM 1994 Energy requirements in cystic fibrosis. In: Dodge JA, Brock DJH, Widdicombe JH (eds) Cystic Fibrosis - Current Topics. John Wiley \& Sons, Chichester, pp 235-254

7. McCloskey M, Redmond AO, Pyper S, McCabe C, Westerterp KR, Elborn JS 2001 Total energy expenditure in stable patients with cystic fibrosis. Clin Nutr 20:235-241

8. Bronstein MN, Davies PS, Hambidge KM, Accurso FJ 1995 Normal energy expenditure in the infant with presymptomatic cystic fibrosis. J Pediatr 126:28-33

9. Borowitz D 1996 The interrelationship of nutrition and pulmonary function in patients with cystic fibrosis. Curr Opin Pulm Med 2:457-461

10. Kerem E 1997 The role of Pseudomonas aeruginosa in the pathogenesis of lung disease in cystic fibrosis: more questions than answers. Pediatr Pulmonol 16:265-266

11. Cripps AW, Dunkley ML, Clancy RL, Kyd J 1995 Pulmonary immunity to Pseudomonas aeruginosa. Immunol Cell Biol 73:418-424

12. Koch C, Hoiby N 1993 Pathogenesis of cystic fibrosis. Lancet 341:1065-1069

13. Vic P, Ategbo S, Gottrand F, Launay V, Loeuille GA, Elian JC, Druon D, Farriaux JP, Turck D 1997 Nutritional impact of antipseudomonas intravenous antibiotic courses in cystic fibrosis. Arch Dis Child 76:437-440

14. Shepherd RW, Holt TL, Cleghorn G, Ward LC, Isles A, Francis P 1988 Short-term nutritional supplementation during management of pulmonary exacerbations in cystic fibrosis: a controlled study, including effects of protein turnover. Am J Clin Nutr 48:235-239

15. Steinkamp G, Drommer A, von der H 1993 Resting energy expenditure before and after treatment for Pseudomonas aeruginosa infection in patients with cystic fibrosis. Am J Clin Nutr 57:685-689

16. Doring G, Conway SP, Heijerman HG, Hodson ME, Hoiby N, Smyth A, Touw DJ 2000 Antibiotic therapy against Pseudomonas aeruginosa in cystic fibrosis: a European consensus. Eur Respir J 16:749-767

17. Goran MI 1995 Variation in total energy expenditure in humans. Obes Res Supp $1: 59-66$

18. Bell SC, Saunders MJ, Elborn JS, Shale DJ 1996 Resting energy expenditure and oxygen cost of breathing in patients with cystic fibrosis. Thorax 51:126-131

19. Buchdahl RM, Cox M, Fulleylove C, Marchant JL, Tomkins AM, Brueton MJ, Warner JO 1988 Increased resting energy expenditure in cystic fibrosis. J Appl Physiol 64:1810-1816

20. Fried MD, Durie PR, Tsui LC, Corey M, Levison H, Pencharz PB 1991 The cystic fibrosis gene and resting energy expenditure. J Pediatr 119:913-916

21. Spicher V, Roulet M, Schutz Y 1991 Assessment of total energy expenditure in free-living patients with cystic fibrosis. J Pediatr 118:865-872

22. Vaisman N, Pencharz PB, Corey M, Canny GJ, Hahn E 1987 Energy expenditure of patients with cystic fibrosis. J Pediatr 111:496-500

23. Girardet JP, Tounian P, Sardet A, Veiberg F, Grimfeld A, Tournier G, Fontaine JL 1994 Resting energy expenditure in infants with cystic fibrosis. J Pediatr Gastroenterol Nutr 18:214-219

24. Thomson MA, Wilmott RW, Wainwright C, Masters B, Francis PJ, Shepherd RW 1996 Resting energy expenditure, pulmonary inflammation, and genotype in the early course of cystic fibrosis. J Pediatr 129:367-373

25. Osika E, Cavaillon JM, Chadelat K, Boule M, Fitting C, Tournier G, Clement A 1999 Distinct sputum cytokine profiles in cystic fibrosis and other chronic inflammatory airway disease. Eur Respir J 14:339-346

26. Vinton NE, Padman R, Davis M, Harcke HT 1999 Effects of Pseudomonas colonization on body composition and resting energy expenditure in children with cystic fibrosis. JPEN J Parenter Enteral Nutr 23:233-236

27. Naon H, Hack S, Shelton MT, Gotthoffer RC, Gozal D 1993 Resting energy expenditure. Evolution during antibiotic treatment for pulmonary exacerbation in cystic fibrosis. Chest 103:1819-1825

28. Castro M, Diamanti A, Gambarara M, Bella S, Lucidi V, Papadatou B, Ferretti F, Rosati P, Rupi E 2002 Resting energy expenditure in young patients with cystic fibrosis receiving antibiotic therapy for acute respiratory exacerbations. Clin Nutr 21:141-144

29. Smith AL 1986 Antibiotic therapy in cystic fibrosis: evaluation of clinical trials J Pediatr 108:866-870

30. Sempé, Pedron G, Roy-Pernod MP 1979 Z-score for weight/height according to French population. In: Sempé (ed) Auxology, Methods and Sequences. Théraplix, Paris, France, pp 1-63

31. Weir JB 1949 New methods for calculating metabolic rate with special reference to protein metabolism. J Physiol 109:1-9

32. Simonson DC, DeFronzo RA 1990 Indirect calorimetry: methodological and interpretative problems. Am J Physiol 258:E399-E412 
33. Ashley MA, Broomhead L, Allen JR, Gaskin KJ 2001 Variations in the measurement of resting energy expenditure in children with cystic fibrosis. Eur J Clin Nutr 55:896-901

34. Molnar D, Schutz Y 1998 Fat oxidation in non-obese and obese adolescents: Effect of body composition and pubertal development. J Pediatr 132:98-104

35. Schulze K, Stefanski M, Masterson J, Kashyap S, Sanocka U, Forsyth M, Ramakrishnam R, Dell R 1986 An analysis of the variability in estimates of bioenergetic variables in preterm infants. Pediatr Res 20:422-427

36. Béghin L, Budniok T, Vaksmann G, Boussard-Delbecque L, Michaud L, Turck D, Gottrand F 2000 Simplification of the method of assessing daily and nightly energy expenditure in children, using heart rate monitoring calibrated against open circuit indirect calorimetry. Clin Nutr 19:425-435

37. Béghin L, Michaud L, Guimber D, Vaksmann G, Turck D, Gottrand F 2002 Assessing sleeping energy expenditure in children using heart-rate monitoring calibrated against open-circuit indirect calorimetry: a pilot study. Br J Nutr 88:533-543

38. World Health Organization Energy and protein requirements 1985 Report of a Join FAO/WHO/UNU Expert Consultation. Technical Report Series Geneva WHO: 724

39. Livingstone MB, Robson PJ, Totton M 2000 Energy expenditure by heart rate in children: an evaluation of calibration techniques. Med Sci Sports Exerc 32:15131519

40. Spurr GB, Prenctice AM, Murgatroyed PR, Golberg GR, Reina JC, Christman NT 1988 Energy expenditure from minute-by-minute heart-rate recording: comparison with indirect calorimetry. Am J Clin Nutr 48:552-559

41. Livingstone MB, Coward WA, Prentice AM, Davies PS, Strain JJ, McKenna PG, Mahoney CA, White JA, Stewart CM, Kerr MJ 1992 Daily energy expenditure in free-living children: comparison of heart-rate monitoring with the doubly labeled water ${ }^{2} \mathrm{H}_{2}{ }^{18} \mathrm{O}$ method. Am J Clin Nutr 56:343-352

42. Bitar A, Vermorel M, Fellmann N, Bedu M, Chamoux A, Coudert J 1996 Heart rate recording method validated by whole body indirect calorimetry in 10-yr-old children. J Appl Physiol 81:1169-1173

43. Schaefer F, Georgi M, Zieger A, Scharer K 1994 Usefulness of bioelectric impedance and skinfold measurements in predicting fat-free mass derived from total body potassium in children. Pediatr Res 35:617-624

44. Benhke AR, Wilmore JH 1974 Assessment of skinfold thicknesses. In: Englewood C (eds) Evaluation and regulation of body build and composition. New-York, pp 1-175

45. Brook CG 1971 Determination of body composition of children from skinfold measurements. Arch Dis Child 46:182-184

46. Durnin JV, Rahaman MM 1967 The assessment of the amount of fat in the human body from measurements of skinfold thickness. Br J Nutr 21:681-689

47. Goran MI, Driscoll P, Johnson R, Nagy TR, Hunter G 1996 Cross-calibration of body-composition techniques against dual-energy X-ray absorptiometry in young children. Am J Clin Nutr 63:299-305

48. Cameron N 1978 The methods of anxological anthropometry. In Falkner F. Tanner JM eds. Human growth. 2 Postnatal growth. New York: Plenum Press 35-90
49. Lukaski HC, Bolonchuk WW, Hall CB, Siders WA 1986 Validation of tetrapolar bioelectrical impedance method to assess human body composition. J Appl Physiol 60:1327-1332

50. Sallis JF 1991 Self-report measures of children's physical activity. J Sch Health 61:215-215

51. Rodriguez G, Béghin L, Michaud L, Moreno LA, Turck D, Gottrand F 2002 Comparison of the TriTrac-R3D accelerometer and a self-report activity diary with heart-rate monitoring for the assessment of energy expenditure in children. Br J Nutr $87: 623-631$

52. Ainsworth BE, Haskell WL, Leon AS, Jacobs DR Jr, Montoye HJ, Sallis JF, Paffenbarger RS Jr 1993 Compendium of physical activities: classification of energy costs of human physical activities. Med Sci Sports Exerc 25:71-80

53. Barnard JA, Tapsell LC, Davies PS, Brenninger VL, Storlien LH 2002 Relationship of high energy expenditure and variation in dietary intake with reporting accuracy on 7 day food records and diet histories in a group of healthy adult volunteers. Eur J Clin Nutr 56:358-367

54. Informatic Center for Quality of foods 1993 Pictures of different meals. In: INSERM, ed. Paris, France: pp 1-63

55. Informatic Center for Quality of foods 2001 Compositions Tables. In: Lavoisier (ed) International Medical Editions, Paris, France, pp 1-150

56. Bandini LG, Schoeller DA, Cyr HN, Dietz WH 1990 Validity of reported energy intake in obese and nonobese adolescents. Am J Clin Nutr 52:421-425

57. Chattaway FW, Happold FC, Happold AM 1946 Nutrition of school-children in Leeds. BMJ i:429-435

58. Burdet L, Hugli O, Aubert JD, Schutz Y, Roulet M, Fitting JW 1999 Effect of elective antibiotic therapy on resting energy expenditure and inflammation in cystic fibrosis. Eur J Pediatr 158:711-716

59. Gottrand F, Hankard R, Michaud L, Ategbo S, Dabadie A, Druon D, Turck D 1999 Effect of glucose to fat ratio on energy substrate disposal in children with cystic fibrosis fed enterally. Clin Nutr 18:297-300

60. Hankard R, Gottrand F, Turck D, Carpentier A, Romon M, Farriaux JP 1996 Resting energy expenditure and energy substrate utilization in children with Duchenne muscular dystrophy. Pediatr Res 40:29-33

61. Maffeis C, Pinelli L, Schutz Y 1995 Increased fat oxidation in prepubertal obese children: a metabolic defense against further weight gain? J Pediatr 126:15-20

62. Flatt JP 1987 Dietary fat, carbohydrate balance, and weight maintenance: effects of exercise. Am J Clin Nutr 45:296-306

63. Levy E, Gurbindo C, Lacaille F, Paradis K, Thibault L, Seidman E 1993 Circulating tumor necrosis factor-alpha levels and lipid abnormalities in patients with cystic fibrosis. Pediatr Res 34:162-166

64. Kaplan T, ZeBranek J, McKey R 1991 Use of exercise in the management of cystic fibrosis: short communication about a survey of cystic fibrosis referral centers. Pediatr Pulmonol 10:205-207 